logos_i_ethos_2017_(45)_numer specjalny, s. 123-134

DOI: http://dx.doi.org/10.15633/lie.2341

Piotr Przybył

The Pontifical University of John Paul II in Krakow

\title{
Common Sense in Science
}

\section{Linguistic Aspects of Common Sense}

Common sense (lat.: sensus communis) is associated with right deci-
Piotr Przybył, mgr, doktorant na Wydziale Filozoficznym Uniwersytetu Papieskiego Jana Pawła II w Krakowie, ksiądz katolicki diecezji kaliskiej.

sions or judges based on correct perception of things. The word "common" suggests, that it must be something universal, something common to all people. However, meaning of this concept is not as clear as one can expect. First question one can ask is: "what does it mean that decisions or judgments are right?" On the other hand, there are many similar words like e.g.: good sense, gumption, practical wisdom, ${ }^{1}$ judgment, reason, prudence etc. and it is not easy to clarify and distinguish among them.

More light on this term could be shed by other languages, though it is important to remember that these translations are not straightforward in all contexts. In Polish: "common sense" is translated as rozsądek. This word has two parts: roz-and -sqdzić means: "to pass a judgement". In addition, it is often connected with word: $z d r o w y^{2}$ what does mean that this judge is right. ${ }^{3}$ In German, word Verstand, is a translation of "common sense," but this concept comes from verstehen - "to understand." The French correspondent is bon sense, with emphasis on good or right recognition.

1 Barry Schwartz, American psychologist, in the title of his book, gives his own simple definition of practical wisdom, as "the right way to do the right thing." (B. Schwartz, K. Sharpe, Practical Wisdom: The Right Way to Do the Right Thing, New York 2011.

2 Zdrowy literally means "helathy."

3 See Rozsądek, in: W. Boryś, Słownik etymologiczny języka polskiego, Kraków 2008, p. 522.

4 A German analogue to Polish zdrowy rozsadek, is gesunden Verstand. 


\section{Common Sense in Philosophy}

Equally important as language connections are philosophical meanings of common sense. First mentioning's thereof one can find in Aristotle's philosophy of perception. In On the Soul, ${ }^{5}$ he explains relations between senses used by animals and humans to distinguish things and he claims that to perceive characteristics of them, there must be something more which is related to rationality. This ability of animal soul is universal and this is common sense indeed:

But for the commons we have even now a common sense, not incidentally. There is, then, no special [sense] for them; for if so we should not perceive them otherwise than as stated, as we see the son of Cleon. ${ }^{6}$

The question which elements of human cognition and language are human-specific and which are characteristic of both humans and animals, or whether the differences between humans and animals in his regard are more quantitative or qualitative have been subject to scientific research. Examples include the controversies about the role of recursion in human language, researches concerning the presence of context-free grammar in starlings' songs, the search for grammar in American Sign Language used by Great Apes, semantically compositional syntax in honeybees' dance or elsewhere and many others. ${ }^{7}$

Descartes created his own concept of common sense as a synonym to reason. For him it is an ability common to all people which helps distinguish between true and false:

5 In Greek Peri Psyche, in Latin De anima.

6 Aristotle, On the Soul, 3. 425a 27.

7 See S. Napierała, Comparison of human and animal syntax, an unpublished BA dissertation (2007); and S. Napierała, The Controversies About Recursion in the Narrow Syntax and Language Evolution, an unpublished MA dissertation (2009). 
Good sense ${ }^{8}$ is the best shared-out thing in the world; for everyone thinks he has such a good supply of it that he doesn't want more, even if he is extremely hard to please about other things. Since it's not likely that everyone is mistaken about this, it is evidence that the power of judging well and of telling the true from the false-which is what we properly call "good sense" or "reason"-is naturally equal in all men."

This is something purely different from Aristotle theory, but it gives new way of defining "sensus communis" and that is why the Aristotelian meaning is forgotten today:

Descartes is the source of the most common meaning of "common sense" today: practical judgement. $^{10}$

At the end of 18th century, Thomas Reid founded the so-called Scottish school of Common Sense as an opposition to skepticism of Hume and Locke. As an alternative hypothesis of perception, they proposed a naïve realism - conception, which was based and justified via introspection. In the light of this perspective one should understand the definition of common sense as follows:

If there are certain principles, as I think there are, which the constitution of our nature leads us to believe, and which we are under a necessity to take for granted in the common concerns of life, without being able to give a reason for them - these are what we call the principles of common sense; and what is manifestly contrary to them, is what we call absurd. ${ }^{11}$

8 In French: bon sense.

9 R. Descartes, Discourse on the Method and the Meditations, trans. J. Veitch, New York 2008, p. 11.

10 J. Schaeffer, Sensus Communis: Vico, Rhetoric, and the Limits of Relativism, London-Durham 1990, p. 2.

${ }^{11}$ Ried on Common Sense, in: N. Wolterstorff, Practices of Belief. Selected Essays, vol. 2, New York 2009, p. 376. 
Some principles are common for every people, but no one can justify them, so only human nature enforces us to believe in them, and this is exactly common sense. But in context of Ried's philosophy, this term is not clear, because it is not so easy to find examples of these certain principles in accordance with the definition above. ${ }^{12}$

In the 20th century new light on common sense was shed by George Moore. His philosophy was important part of the beginning of analytic tradition and comeback to realism. In his opinion, common sense is good tool to judge philosophical views and it must be the starting point for creating own philosophy. Analytic philosophers claimed that theorems that are understandable but unexplainable, exist, e.g. cognition. Common sense consists of these convictions. ${ }^{13}$

Given the circumstances, common sense is something like common ability of all people to perceive things correctly and judge them right to make good decisions. They may be other definitions, but this one includes every important part: universality, human acting, epistemology and judging.

Now getting this altogether, one can ask the question - how can common sense exist in science? If one compares the definition above with science, one can see common characteristics: science is something universal, it is human ability, it is about things and relations among them, scientific method is the way of perceiving, theories and its predications are still verified to judge them as true or false.

On the other side, science is very diversified. There are modern science and humanities and each one includes many disciplines with different methods. Is that possible that common sense could be practical and universal tool above all methods? The positive answer one can find in Michal Heller's philosophy.

12 D. Kucharski, Natura przedmiotu spostrzeżenia zmysłowego w ujęciu Thomasa Reida, „Studia Philosophiae Christianae" 48 (2012) nr 3, p. 55-75.

${ }^{13}$ See W. Tatarkiewicz, Historia filozofii, t. 3, Warszawa 2009, p. 256-264. 


\section{Michał Heller’s Philosophy}

Michał Heller is Polish theologian, philosopher, cosmologist, and a Catholic priest. In 2008, he was awarded Templeton's prize ${ }^{14} \mathrm{He}$ is a professor of philosophy at the Pontifical University of John Paul II in Cracow and an adjunct member of the Vatican Observatory staff. His philosophy is interdisciplinary, he connects science, philosophy and theology but not mixes them. He treats them as separated disciplines, but as he believes, in cooperation they can elucidate many problems. His well-known idea is the mathematicity of the World.

Heller, in his global view on science, proposes a universal and objective method - critical rationalism, which is his way of practicing philosophy and science. It is very important to realize that this is not his postulate, but it is just attractive proposition. Critical rationalism is not an original idea of Heller. This concept comes from Karl Popper's philosophy and it is about theories of science:

How can we hope to detect and eliminate error? I believe, by criticizing the theories or guesses of others and - if we can train ourselves to do so - by criticizing our own theories or guesses. [...] This answer sums up a position which I propose to call "critical rationalism".

These sentences should relate to falsificationism, but it is not only about empirical verification, but also about self-reflection in one's own mind. Popper claims that it is impossible to find a certain method to verify possessed knowledge. The only way is to approximate to the truth by continued criticism based on rationality. To understand Popper's idea, it may be necessary to review his whole philosophy, but it is not the point of this article.

14 See Previous Prize-Winners. Michał Heller, http://www.templetonprize.org/previouswinners/ heller.html (15.04.2017).

15 K. Popper, Conjectures and Refutations. The Growth of Scientific Knowledge, London 2002, p. 34. 
Heller in his reflections refers to Popper's views, considering him an inspirer in developing his own philosophical conception, which can qualify Heller to Popperism. Direct reference is evident in Heller's early philosophical searches:

I think that in the history of nature philosophy Popper's thought will also play a key role [...] Representatives of the natural sciences, after acquainting themselves with the views of this philosopher, very often recognize them as their own, ${ }^{16}$

and

If Popper's call for critical rationality becomes a sign of contemporary thought, then at least we will not have to be ashamed of our children. ${ }^{17}$

Also in relation to critical rationalism this similarity of thought is visible. However, as will be shown later, the views of the Polish philosopher are not merely a continuation or a creative development of Popper's thought but a separate and independent worldview. Critical rationalism should therefore be regarded as a certain method of practicing the philosophy that Heller uses, not as belonging to a certain direction in modern philosophy.

In later works Heller no longer writes about critical rationalism, but just applies it. In science, he espouses falsificationism as a criterion for science, analyzes metaphysical assumptions and philosophical concepts applied in science. He is interested in linguistic issues related to the interpretation of theories. Also, he points out problems of multiverse theory and the Theory of Everything. When he speaks about the mathematical nature of the universe, he explicitly states that this is just a hypothesis, as he opposes the creation of any system of the world. All these issues

16 M. Heller, Filozofia świata, Kraków 1992, p. 164-165. Self-translation (in all quotes from Heller's book written in Polish language).

17 M. Heller, Usprawiedliwienie Wszechświata, Kraków 1984, p. 12. 
incudes criticism connected with rationalism. Scientist should not only try to build new theories, but self-reflects on his previous works and discoveries.

\section{Ethics and Methodology}

As shown above, Heller practices critical rationalism in similar way to Popper's. On the other hand, in Heller's philosophy one can find something which is characteristic of him. The greatest difference can be seen in the everyday practice of a scientist and a philosopher. In his book Jak być uczonym?, ${ }^{18}$ what does mean "how to be a scholar?", he connects methodology of science with ethics: ${ }^{19}$

Methodology of work is a collection of technical prescriptions, how to work well. But scientific work is of a special kind. In the scientific work, the collection of techniques will remain powerless if it does not penetrate deeper layers of the psyche. Techniques $[\ldots]$ must transform into a style of being. [...] All this makes the methodology of scientific work must also be its ethics. ${ }^{20}$

But on the other hand:

The ethics of scientific work should seek an alliance with techniques. Ethics without techniques and techniques without ethics are ineffectual. ${ }^{21}$

For this reason, he does not distinguish which of his propositions for scientists are methodological and which are ethical. So, what is the answer for the question - how to be a scholar? There are few elements needed:

18 M. Heller, Jak być uczonym?, Kraków 2009.

19 Sometimes Heller uses words "ethics" and "morality" as synonyms, what is incorrect.

20 M. Heller, Jak być uczonym?, op. cit., p. 17.

21 M. Heller, Jak być uczonym?, op. cit., p. 18. 


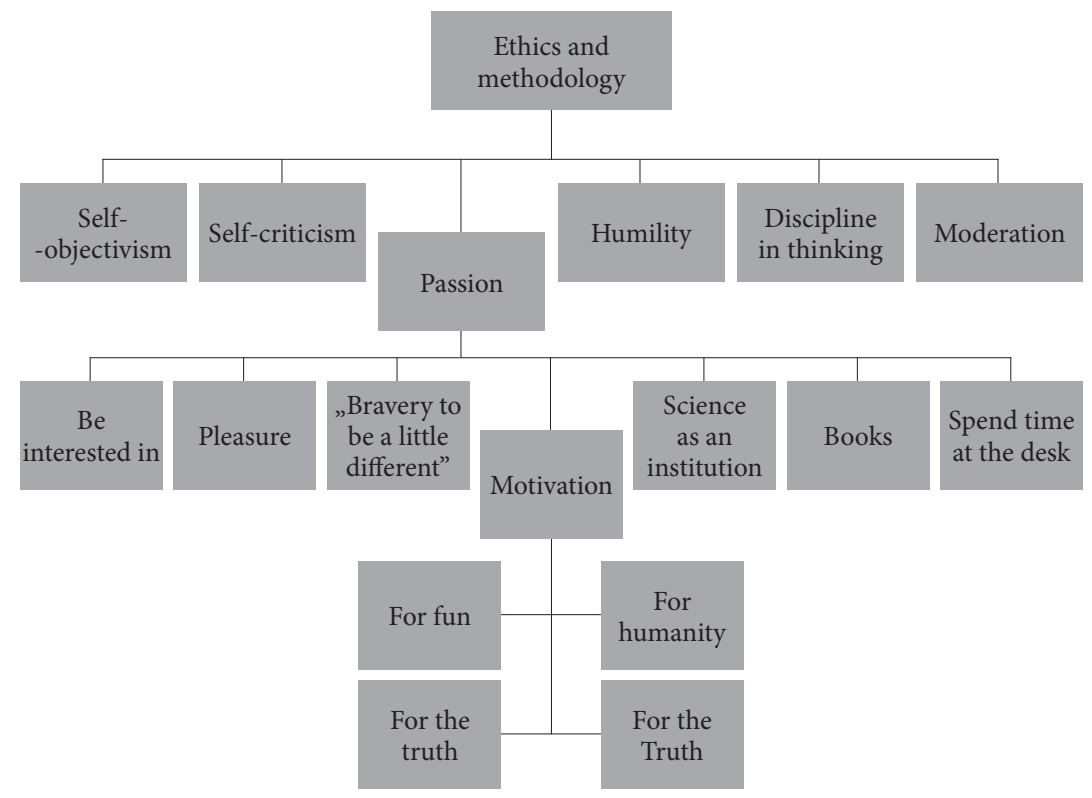

Diagram 1. Ethics and Methodology in Science and Philosophy

First line shows characteristics of the scientist or philosopher. If he wants to find them as his own, he must do an introspection. Self-objectivism is an ability to perceive oneself from many different perspectives. Self-criticism is a capability that helps to reject one's own mentality and way of thinking. Humility is a virtue, which help to judge oneself right, to see oneself advantages, disadvantages, talents, and limits. Discipline in thinking is a good organization of work. Moderation is a happy medium in acting. ${ }^{22}$

Passion, as Heller claims, is a complicated concept. He shows seven aspects of it (presented in the second line). Scientist or philosopher with passion should be interested in subject and find pleasure in researches.

${ }^{22}$ See M. Heller, Jak być uczonym?, op. cit. p. 18-19, and 26-39. 
He must have "bravery to be a little different," because life of scientist or philosopher is unlike the other people's life, even for this reason that he has other priorities and must resign from part of social relations. Every scientist must work in institution - university, laboratory etc., because now it is the only way to practicing science. Everyone, who treats his own discipline seriously, should reeds many books and journals. It is obvious, that all of this involves spending time "at the desk." True passion must be based on real motivation, because without it, passion can fade away. Heller points out, that there are many possible reasons to practice science, but he lists four: for fun, for humanity, for the truth as a value, and for the Truth as God (religious motivation). ${ }^{23}$

As one can see, these things are not strictly methodology and ethics, these are just Heller's thoughts based on his every-day reality. He is very successful, and famous philosopher and cosmologist, and could be an authority and his advices may be very helpful.

Heller points out that except ethics and methodology one more thing is needed to be a true scholar. He names it "an asceticism of science work" and again this concept "asceticism" is not clearly the same as usual meaning. It is not a resignation from something in one's life, it is rather a choice to follow the truth or Truth (logos or Logos). So, except traditional techniques and methods, very helpful is contemplation of the Truth. It could give fascination, and fascination finally is the biggest motivation. This kind of asceticism could be seen as something similar to mysticism and something very different from science, or even contradictory to it. To avoid misunderstandings, Heller underlines the role of self-criticism and common sense in contemplation indeed. ${ }^{24}$

After this reflections on practicing philosophy and science, Heller poses the question: "May philosophy be a way of life?," and gives positive answer. Philosophy as "friendship with Wisdom" 25 is some kind of spirituality and the way of life indeed. In Heller's opinion, the true philosopher

23 See M. Heller, Jak być uczonym?, op. cit., p. 19-23.

${ }^{24}$ See M. Heller, Jak być uczonym?, op. cit., p. 43-52.

25 In Greek: philo sophia. 
has characteristics easy to recognize: openness for discussions, ability to listen with understanding, open-mindedness, clearness of thinking, realism, ${ }^{26}$ self-criticism and intellectual honesty. ${ }^{27}$ Everyone who knows Michał Heller in person, can easily find this characteristic in him and it is the best proof for positive answer for question above.

\section{Summary}

This specific understanding of methodology connected with ethics and even asceticism may give the impression that it is not a critical rationalism. But similarities are clearly visible. First line of diagram shows indispensable elements of self-criticism. The second line outlines what scientist or philosopher needs for gaining knowledge, without which objectivism is impossible. Objectivism and criticism are two main aspects of critical rationalism.

Finally, one more question - is critical rationalism a common sense applied to science? Let's remind the definition of common sense - it is common ability of all people to perceive things correctly and judge them right to make good decisions. If one looks back to elements of critical rationalism in Heller's philosophy, easily can find human abilities like self-criticism, passion, virtues like humility, moderation, and discipline (first line of diagram). Criticism connected with rationality is verification of perceiving things. Moreover, self-criticism is very helpful in making good decisions, because it is self-reflection and it is recognition of one's motivation, and reasons. In a word, critical rationalism is commonsensical way of practicing science.

\section{Bibliography}

Aristotle, De anima, trans. M. Shiffman, Indianapolis-Cambridge 2011.

Boryś W., Słownik etymologiczny języka polskiego, Kraków 2008.

${ }^{26}$ Not as epistemological statement, rather as a real recognition.

27 See M. Heller, Jak być uczonym?, op. cit., p. 55-64. 
Descartes R., Discourse on the Method and the Meditations, trans. J. Veitch, New York 2008. Heller M., Filozofia świata, Kraków 1992.

Heller M., Jak być uczonym?, Kraków 2009.

Heller M., Usprawiedliwienie Wszechświata, Kraków 1984.

Kucharski D., Natura przedmiotu spostrzeżenia zmysłowego w ujęciu Thomasa Reida, „Studia Philosophiae Christianae” 48 (2012) nr 3, s. 55-75

Napierała S., Comparison of human and animal syntax, an unpublished BA dissertation (2007).

Napierała S., The Controversies About Recursion in the Narrow Syntax and Language Evolution, an unpublished MA dissertation (2009).

Popper K., Conjectures and Refutations. The Growth of Scientific Knowledge, London 2002. Previous Prize-winners. Michal Heller, http://www.templetonprize.org/previouswinners/ heller.html (14.02.2016).

Ried on Common Sense, in: N. Wolterstorff, Practices of Belief. Selected Essays, vol. 2, New York 2009.

Schaeffer J., Sensus Communis: Vico, Rhetoric, and the Limits of Relativism, LondonDurham 1990.

Schwartz B., Sharpe K., Practical Wisdom: The Right Way to Do the Right Thing, New York 2011.

Tatarkiewicz W., Historia filozofii, t. 3, Warszawa 2009.

\section{Abstract}

\section{Common Sense in Science}

Common sense is an ability common to all people and it is related to right judges based on correct perception. These elements are very important in science too, so common sense could be a universal method of dialog among different disciplines. Critical rationalism of Karl Popper, as a method of verification theories, is a reflection about human perception, it is the way to know the truth and it is objective judging. Polish philosopher Michał Heller points out a characteristics which are necessary to be a good scientist and philosopher: self-criticism, objectivism, and discipline in thinking etc., which are common with Popper's idea. The aim of this article is to show that Heller's critical rationalism is commonsensical way of practicing science and philosophy. 


\section{Keywords}

common sense, science, philosophy, Michał Heller, critical rationalism

\section{Abstrakt}

\section{Zdrowy rozsądek w nauce}

Zdrowy rozsądek jest zdolnością wspólną dla wszystkich ludzi i jest związany z właściwymi sądami opartymi na poprawnym poznaniu. Te elementy są również bardzo ważne w nauce, więc zdrowy rozsądek może być uniwersalną metodą dialogu pomiędzy różnymi dyscyplinami. Krytyczny racjonalizm Karla Poppera jako metoda weryfikacji teorii jest refleksją nad ludzkim poznaniem, sposobem poznawania prawdy i obiektywnym osądzaniem. Polski filozof Michał Heller wskazuje kilka cech charakteru, które są konieczne, by być dobrym naukowcem lub filozofem i które są wspólne z ideą Poppera: samokrytycyzm, obiektywizm, dyscyplina w myśleniu itd. Celem tego artykułu jest pokazanie, że krytyczny racjonalizm Hellera jest zdroworozsądkowym sposobem uprawiania nauki i filozofii.

\section{Słowa klucze}

zdrowy rozsądek, nauka, filozofia, Michał Heller, krytyczny racjonalizm 